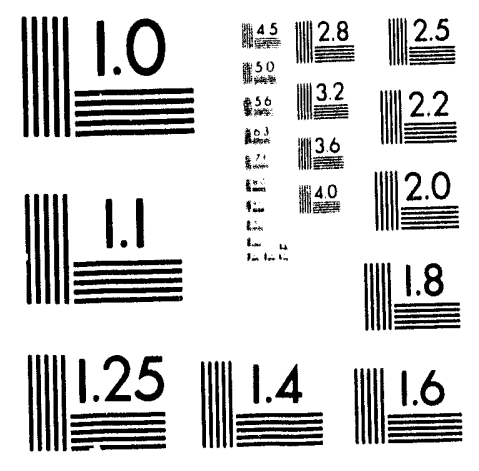



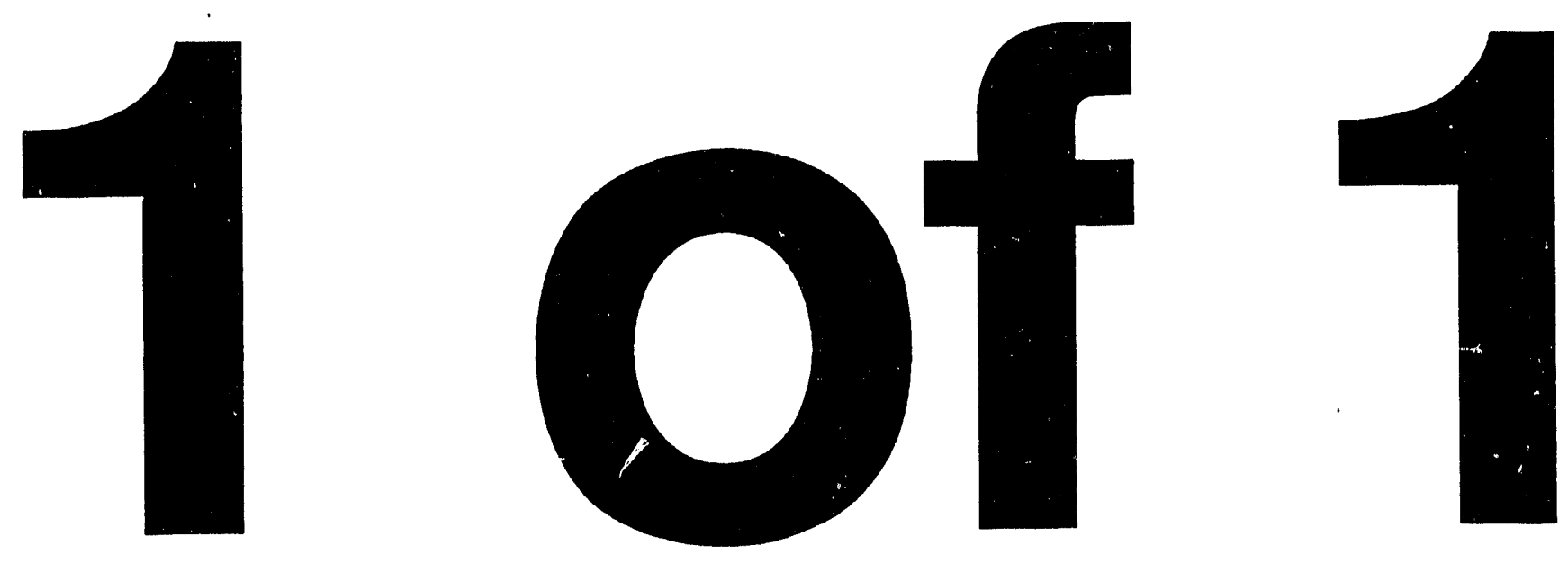


\section{INVESTIGATION OF NATURAL LATEX RUBBER GLOVES}

(U)

by

E. M. Vessell

Westinghouse Savannah River Company

Savannah River Site

Aiken, South Carolina 29808

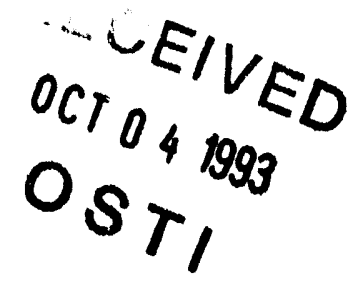

\section{DOE Contract No. DE-AC09-89SR18035}

This paper was prepared in connection with work done under the above contract number with the U. S. Department of Energy. By acceptance of this paper, the publisher and/or recipient acknowledges the U.S. Government's right to retain a nonexclusive, royalty-free license in and to any copyright covering this paper, along with the right to reproduce and to authorize others to reproduce all or part of the copyrighted paper.

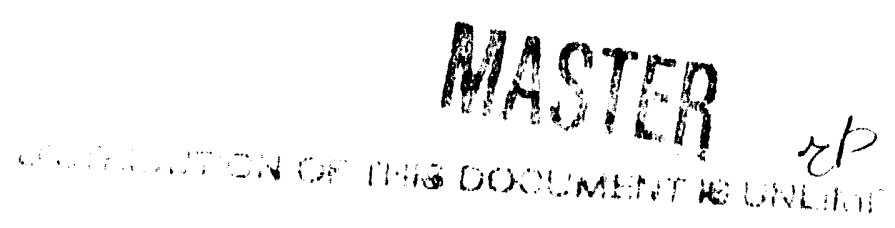


KEYWORDS:

Laboratory

Protective Clothing

Hands

Latex Rubber Gloves

RETENTION - Permanent

INVESTIGATION OF NATURAL LATEX RUBBER GLOVES

(U)

E.M. Vessel

SAVANNAH RIVER TECHNOLOGY CENTER

Materials Technology Section

Publication Date: March 19, 1993

Westinghouse Savannah River Company

Savannah River Site

Alken, SC 29802 


\section{DISCLAIMER}

This report was prepared as an account of work sponsored by an agency of the United States Government. Neither the United States Government nor any agency thereof, nor any of their employees, makes any warranty, express or implied, or assumes any legal liability or responsibility for the accuracy, completeness, or usefulness of any information, apparatus, product, or process disclosed, or represents that its use would not infringe privately owned rights. Reference herein to any specific commercial product, process, or service by trade name, trademark, manufacturer, or otherwise does not necessarily constitute or imply its endorsement, recommendation, or favoring by the United States Government or any agency thereof. The views and opinions of authors expressed herein do not necessarily state or reflect those of the United States Government or any agency thereof.

This report has been reproduced directly from the best available copy.

Available to DOE and DOE contractors from the Office of Scientific and Technical Information, P. O. Box 62, Oak Ridge, TN 37831; prices available from (615) $576-8401$.

Available to the public from the National Technical Information Service, U. S. Department of Commerce, 5285 Port Royal Rd., Springfield, VA 22161 


\section{CONTENTS}

EXECUTIVE SUMMARY

INTRODUCTION 1

EXPERIMENTAL PROCEDURE

Chemical Resistance 2

Mechanical Testing

Permeability

RESULTS

Chemical Analysis $\quad 4$

Mechanical Testing 4

Permeation 5

DISCUSSION 5

CONCLUSIONS

ACKNOWLEDGMENTS 6

REFERENCES

TABLES 8

FIGURES 15 
APPROVALS

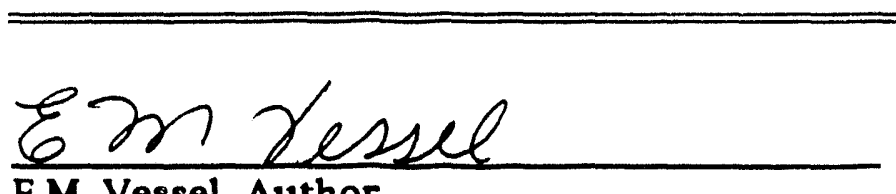

E.M. Vessel, Author

Materials Consultation Group

Materials Technology Section SRTC

Elliot A. Clunk
Date: $4 / 19 / 93$

Date: $4 / 27 / 93$

E.A. Clark, Technical Reviewer

Materials Compatibility \& Joining Technology Group

Materials Technology Section

SRTC

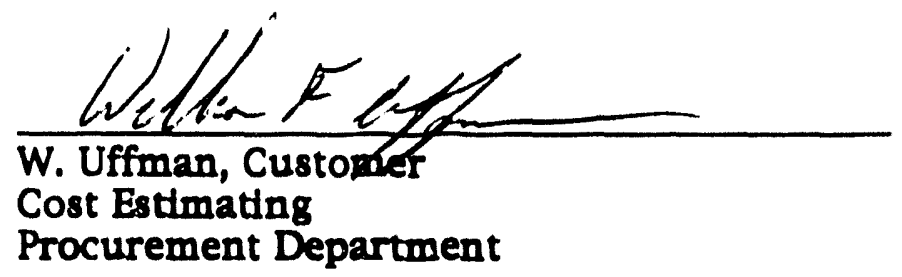

Date: $5 / 12 / 93$

Pysichtord

R.L. Bigkford, Manager

Maternal Consultation Group

Materials Technology Section SRTC

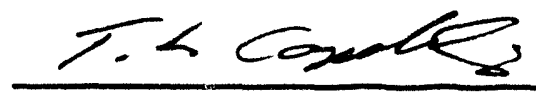

T.L. Capeletti, Manager Materials Technology Section SRTC
Date: $4 / 19 / 93$

Date: $4 / 20 / 53$

iii 


\title{
INVESTIGATION OF NATURAL LATEX RUBBER GLOVES
}

\author{
E.M. Vessel \\ Westinghouse Savannah River Company \\ Savannah River Site \\ Aiken, SC 29802
}

\section{EXECUTIVE SUMMARY}

Seventy five percent of natural latex rubber gloves used in laboratories at the Savannah River Site are not reused. A cost analysis performed by the SRS Procurement Department determined that a net savings of $\$ 1,092,210$ could be achieved annually by recycling latex rubber gloves. The Materials Technology Section, at the request of the Procurement Department, examined some mechanical and chemical properties of latex rubber gloves manufactured by Ansell Edmont, which had been purchased by the site specifications for protective clothing. It also examined mechanical properties of re-cycled gloves purchased by specifications and of "off the shelf" gloves manufactured by North Brothers Company. Finally, water vapor transmission studies, simulating tritium permeation, were performed on gloves from both manufacturers. These studies were performed to determine whether latex rubber gloves can be recycled or whether using only new, unwashed gloves is required in areas where tritium exposure is a possibility.

The results of these studies indicate that the acceptable glove characteristics, required in the WSRC Manual 5Q1.11, Protective Clothing Specifications, are not adversely affected after washing and drying the gloves manufactured by Ansell Edmont for seven cycles. Results also indicate that natural latex rubber gloves manufactured by North Brothers comply with most of the acceptable glove characteristics specified in the WSRC Manual 5Q1.11. Statistical analysis of the water vapor permeation data show that there is no correlation between permeation rates and the manufacturer.

\section{INTRODUCTION}

Natural latex rubber gloves are used in general laboratory work for protection against various aqueous solutions of acids, alkalies and radioactive contaminants at the Savannah River Site. Gloves must conform to acceptable physical, chemical and mechanical requirements specified in Westinghouse Savannah River Company Manual 5Q1.11, Protective Clothing Specifications (See Tables 1 and 2). Gloves are also required to be capable of withstanding repeated washing and drying.

Rubber and rubber products must withstand tensile forces for adequate performance when used as glove material. Tensile strength in rubber refers to the force per unit of original cross section on elongation to rupture. Tensile characteristics are the most widely reported mechanical properties of any 
material.(1) Properties which improve with tensile strength are wear and tear resistance, resilience, cut resistance, stress relaxation and creep.

The tensile properties of rubber depend on both material and conditions of test, such as temperature, humidity, environment or mechanical preconditioning. ASTM- D412 is used to measure the tensile properties of elastomers. A "dumb-bell" shaped specimen is most often used with pneumatic grips that tighten automatically to prevent slipping as the specimen tabs thin under load. Gage lengths of 1 or 2 inches are defined by inked bench marks on the specimen.

Elongation, tension set and aging effects are also used to measure performance of rubber products. Elongation, the maximum extension of a rubber at the moment of rupture, is determined by measuring the separation of the gage marks with a rule held close to the specimen while loading. Tension set represents residual deformation which is partly recoverable after stretching and retraction. Aging is a deteriorative process which could be caused by sunlight, heat, stress with atmospheric ozone, atmospheric moisture or atmospheric nitrous oxide.

\section{EXPERIMENTAL PROCEDURE}

\section{CHEMICAL RESISTANCE}

Chemical resistance tests were performed on "as received" samples cut from gloves manufactured by Ansell Edmont with 1990 and 1992 dates stamped on the gloves. Two inch diameter samples were immersed in each of the following chemicals for 8 hours: $48 \%$ hydrofluoric acid, $50 \%$ nitric acid, $50 \%$ sulfuric acid, $37 \%$ hydrochloric acid and $50 \%$ sodium hydroxide.

\section{MECHANICAL TESTING}

Tensile properties were measured on dumb-bell shaped specimens stamped from gloves manufactured by Ansell Edmont and North Brothers Company per ASTM D-412. Minimum thickness measurements were recorded from glove paim, back and finger crotch areas per WSRC 5Q1.11. The North Brothers gloves were tested in the "un-washed" condition. The Ansell Edmont gloves, with both 1990 and 1992 manufacture dates, were tested in the "un-washed" condition and after laundering up to seven times. Tensile strength and ultimate elongation percent were measured on samples in the "as received" condition and after heat aging, immersion in either distilled water, sodium hydroxide, sulfuric acid or nitric acid. Acceptable glove characteristics, listed in the site specifications for protective clothing, are given in Table 2.

\section{PERMEABILITY}

The transmission of molecules through polymer films is named "permeability". The process of permeation in elastomers generally is one of solution of the gas molecules on one surface of the material, followed by diffusion through the elastomer to the other side. The amount of permeating species existing on the 
reverse side of the membrane per unit time can be described by the steady state permeation of gases through polymers. (3)

Tritium oxide (HTO) is much more toxic than tritium (HT) and so presents a radiological hazard to workers. Tritium water vapor penetrates through a wide variety of rubbers and plastics. The use of protective gloves play a major role in reducing exposure to tritium. In some facilities where tritium is handled, the greatest occupational dose is received via the permeation of tritium oxide through protective material. (2) When selecting materials for protective clothing against tritium or tritium oxide, permeability is a primary consideration.

Permeation rates through films can be measured by one of several methods depending on transmission principles. The most common methods involve measurement of pressure, volume and concentration related variables. The test procedure chosen for this work was ASTM Designation: E96-90, the water method. Normal water vapor data has been used to estimate tritium permeation rates since permeation rates of tritiated species are the same as that of protium species in polymers within experimental error. $(3)$

Four sets of samples were cut from smooth and textured areas of gloves from both manufactururs. The thickness of each specimen was measured in four places (center of each quadrant) and averaged. The diameter of each specimen was measured using a ruler, and each specimen was weighed on an analytical balance. Twelve of sixteen total test dishes were filled with water to within $1 / 4$ inch of the specimens. The other four were used for control measurements. The sixteen specimens were attached to each of the test dishes, via a sealant impermeable to water, and the assembly weighed. The dishes were then place in an environmental chamber and weighed periodically. The test temperature and relative humidity in the test chamber were $28^{\circ} \mathrm{C}$ and $88 \%$ respectively.

The change in the quantity of water was plotted versus the change in the time to obtain a straight line (Figures 4 - 7). The slope from this line was multiplied by the measured specimen thickness and divided by the product of the specimen area times the vapor pressure difference across the film. The permeability coefficient is used to express the permeability of water vapor through natural latex rubber. It has the dimensions:

$P=($ quantity of permeant $) X($ film thickness (area) $\mathbf{X}$ (time) $\mathbf{X}$ ( pressure drop across the film)

The units found in the literature to express permeability and used in this study are:

$$
\mathrm{P}=\frac{\mathrm{cm}^{3} \frac{\mathrm{cm}}{\mathrm{cm}^{2}} \mathrm{~s} \mathrm{~Pa}}{2}
$$

Literature values for permeability of water vapor through natural rubber is

$$
1720 \times 10^{-13} \frac{\mathrm{cm}^{3} \mathrm{~cm}^{2} \mathrm{~s} \mathrm{~Pa}}{\mathrm{~cm}^{2}}
$$


Permeability values for latex rubber gloves are not spe-ified in Manual 5Q1.11, therefore permeability rates measured in this study weie compared to literature values.

\section{RESULTS}

\section{CHEMICAL ANALYSIS}

Rubber gloves manufactured by Ansell Edmont were exposed to chemicals specified in WSRC Manual 5Q1.11, the Protective Clothing Specifications, with the following results:

(1) Exposure to hydrofluoric acid, nitric acid and sulfuric acid produced no notable change in the physical appearance of the 1990 or 1992 glove material after 8 hours.

(2) After exposure to hydrochloric acid for 2 hours the 1992 glove samples were starting to turn dark. However, they still retained most of their elasticity. After 8 hours exposure to hydrochloric acid, the 1990 and 1992 glove material was dark and brittle.

(3) After only 2 hours of exposure to nitric acid, a noticeable loss in elastic properties could be seen in the 1992 samples. After 8 hours the 1990 and 1992 samples were extremely brittle.

\section{MECHANICAL TESTING}

Tensile measurements and elongation percent for gloves manufactured by Ansell Edmont and North Brothers are given in Tables $3-11$ and Figures $1-3$. Specimens from gloves manufactured by North Brothers, in the "unwashed" condition, were tested for ultimate tensile strength, ultimate elongation percent and tension set. All specimens complied with acceptable glove characteristics specified in WSRC Manual 5Q1.11 except tensile samples immersed in distilled water and heat aged (See Figure 1).

Specimens from gloves manufactured by Ansell Edmont, in the "unwashed" condition and after up to 7 wash-dry cycles, were tested for ultimate tensile strength, ultimate elongation percent and tension set. All 1990 and 1992 samples complied with the acceptable glove characteristics specified in the protective clothing specification. Although some tensile measurements after washing and exposure to nitric acid appeared erratic and were less than 1600 psi, tensile strength after exposure to nitric acid was not specified in the protective clothing specification. Therefore all glove samples complied with the required specifications. 


\section{PERMEATION}

Permeability of water vapor through the gloves manufactured by North Brothers and Ansell Edmont are given in Tables 12 and 13. The values appear to be in the range of literature values for natural rubber. Permeability through samples from smooth areas of gloves were compared with samples from textured areas. "Dummy" samples versus real samples were also examined.

Statistical analysis of data from this report was performed using the statistical software "JMP"(5). 95\% confidence curves show the correlation between two variables in the model. When no correlation between the variables exists the confidence curves do not intersect the horizontal line in the middle of the leverage plot. Borderline correlation occurs when the curves are asymptotic to the horizontal line, and correlation exists when the confidence curves intersect the horizontal line. The analysis was first used to determine whether permeation of water vapor through the glove material was dependent on the manufacturer. The analysis showed no correlation between manufacturer and permeation rates (See Figure 8). The analysis was then used to determine if the rate of transmission varied depending on the finish of the glove material. No correlation between smooth and textured samples was indicated (Figure 9). Finally, the analysis was used to determine if there was a difference in permeation rate between samples which initially had water in the test dishes and those which did not (dummy samples). The analysis showed that there is a correlation between "dummy" and real samples (see Figure 10).

\section{DISCUSSION}

The chemical composition of the gloves manufactured in 1990 and 1992 by Ansell Edmont appears to have been changed somewhat. In chemical tests, the 1992 glove samples began to show signs of deterioration after two hours of exposure to nitric and hydrochloric acids. The 1990 samples were generally unchanged at that point. Further support for the change in composition can be seen in the measured values for the ultimate tensile strength after exposure to nitric acid. Both the 1990 and 1992 samples exhibited a decrease, however the ultimate tensile strength in the 1992 was significantly lower than the 1990 samples(See Figures 1 and 2) 


\section{CONCLUSIONS}

As a result of mechanical testing and permeation studies of latex rubber gloves manufactured by North Brothers and Ansell Edmont, the following conclusions are drawn:

(1) Natural latex rubber gloves, "off the shelf", manufactured by North Brothers, complied with specified tensile requirements in the following conditions: as-received, and after exposure to sulfuric acid and after exposure to sodium hydroxide. Ultimate tensile strength after heat aging and after immersion in distilled water was slightly lower than the specification in Manual 5Q1.11 for protective clothing. All elongation percent samples complied with all specifications except the as-received samples.

(2) Re-cycling latex rubber gloves, manufactured by Ansell Edmont, does not affect the acceptable glove characteristics specified in the protective clothing specifications.

(3) Permeability of water vapor through gloves manufactured by North Brothers and Ansell Edmont are very similar and both are within the scope of literature values.

\section{ACKNOWLEDGMENTS}

Mechanical testing of the samples was performed by W.B. Burkett and C.C. Posey of the Reactor Materials Quality Department. Water vapor transmission sample preparation and weighings were performed by Susan Hatcher of the Materials Technology Section. Technical assistance with statistical analysis of permeation data was provided by E.A. Clark of the Materials Technology Section. The assistance of everyone above in completion of these studies is gratefully acknowledged. 


\section{REFERENCES}

1. "Mechanical-Properties Tests", Handbook of Plastics and Elastomers. A. Harper, Ed. Copyright 1975 by McGraw-Hill. pp3-6 through 3-8.

2. T.P Fuller and C.E. Easterly. "Tritium Protective Clothing", ORNL/TM-6671 . Oak Ridge National Laboratory . Oak Ridge, Tennessee, 37830. operated by Union Carbide Corporation for the Department of Energy.

3. E.A. Clark. Permeability of Molecular Hydrogen and Water Vapor Through Butyl Rubber at Ambient Temperature. Report WSRC-TR-92305. Westinghouse Savannah River Company, Aiken, SC 29802. (April 9, 1992).

4. S. Pauly. "Permeability and Diffusion Data" in Polymer Handbook, ed. J. Brandrop and EH. Immergut. Wiley-Inter science, pp.VI/435-VI/449 (1989).

5. "JMP", Version 1.04, SAS Institute, Inc., Box 8000, SAS Circle, Cary, NC 27512-8000 (1989).

6. R.H. Steinmeyer and J.D. Braun. Hydrogen Isotope Permeation In Elastomeric Materials, in Radiation Effects and Tritium Technology for Fusion Reactors", Proceedings of the International Conference held at Gatlinburg, TN October 1-3 1975. Conf-750989, ed J.S.. Watson and F.W. Griffen,

Volume IV, Oak Ridge National Laboratory, Oak Ridge, TN (March 1976).

7. Westinghouse Savannah River Company Manual 5Q1.11, Procedure 38, Rev. 5 Protective Clothing Specifications.

8. ASTM D-412-87. "Standard Test Methods for Rubber Properties in Tension". Annual Book of ASTM Standards.

9. ASTM E:96-90. "Standard Test Methods for Water Vapor Transmission of Materials". 1991 Annual Book of ASTM Standards, Vol. 4.06. American Society for Testing and Materials, Philadelphia, PA (1991).

10. Westinghouse Standard Operating Procedure 322 STP 89T. "Latex Rubber Glove Test", Manual SR2.1, Rev. 0. 
TABLE 1

Chemical Resistance - Design Conditions

\begin{tabular}{|l|l|l|}
\hline Chemical & Concentration & $\begin{array}{l}\text { Min. Breakdown } \\
\text { Time }\end{array}$ \\
\hline Hydrofluoric acid & $48 \%$ & 8 Hours \\
\hline Nitric acid & $50 \%$ & 8 Hours \\
\hline Sulfuric acid & $50 \%$ & 8 Hours \\
\hline Hydrochloric acid & $37 \%$ & 8 Hours \\
\hline Sodium hydroxide & $50 \%$ & 8 Hours \\
\hline
\end{tabular}

TABLE 2

Acceptable Glove Characteristlcs

\begin{tabular}{|l|l|l|}
\hline 1 & $\begin{array}{l}\text { Tensile Strength, } \\
\text { psi }\end{array}$ & \\
\hline & Initial & 4,500 Min. \\
\hline & After Aging & 4,000 Min. \\
\hline & $\begin{array}{l}\text { After immersion in } \\
\text { Distilled Water }\end{array}$ & 3,700 Min. \\
\hline & $\begin{array}{l}\text { Uitimate } \\
\text { Elongation, } \\
\text { percent }\end{array}$ & \\
\hline & Initial & 800 Min. \\
\hline & After Aging & 700 Min. \\
\hline 3 & $\begin{array}{l}\text { After immersion in } \\
\text { Distilled Water }\end{array}$ & 700 min. \\
\hline 4 & $\begin{array}{l}\text { Tension Set, } \\
\text { percent }\end{array}$ & 10.0 Max. \\
\hline & Thickness, mills & \\
\hline & palm, back & 18 mils \\
\hline & finger crotch & 16 mils \\
\hline
\end{tabular}


Table 3

Mechanical Propertles of North Brothers Gloves

\begin{tabular}{|l|l|l|}
\hline Test Grou? & $\begin{array}{l}\text { Uidmate Tensile } \\
\text { Strength, pol }\end{array}$ & $\begin{array}{l}\text { Utimate } \\
\text { Elongation, } \\
\text { percent }\end{array}$ \\
\hline As Received & 4716 & 760 \\
\hline Heat Aged & 3749 & 700 \\
\hline Distilled Water & 2952 & 742 \\
\hline $\mathrm{HNO}_{3}$ & 4145 & 750 \\
\hline $\mathrm{H}_{2} \mathrm{SO}_{4}$ & 3865 & 708 \\
\hline $\mathrm{NaOH}$ & 4220 & 742 \\
\hline
\end{tabular}

Values for ultimate tensile strength and ultimate elongation are average values from three teat samples.

Total teneile eet gage length percent was $2 \%, 3 \%$ and $3 \%$ from three "as recelved" aamples. 
Table 4

Mechanical Propertles from Ansell Edmont Gloves

(Un-washed)

\begin{tabular}{|l|l|l|l|l|}
\hline $\begin{array}{l}\text { Test } \\
\text { Group }\end{array}$ & $\begin{array}{l}\text { Utimate } \\
\text { Tensile } \\
\text { Strength, } \\
\text { psi } \\
1990\end{array}$ & $\begin{array}{l}\text { Uitimate } \\
\text { Tensile } \\
\text { Strength, } \\
\text { psi } \\
1992\end{array}$ & $\begin{array}{l}\text { Uitimate } \\
\text { Elongation, } \\
\text { percent } \\
1990\end{array}$ & $\begin{array}{l}\text { Uitimate } \\
\text { Elongation, } \\
\text { percent } \\
1992\end{array}$ \\
\hline $\begin{array}{l}\text { As } \\
\text { Received }\end{array}$ & 5355 & 5639 & 821 & 813 \\
\hline Heat aged & 4769 & 4582 & 721 & 725 \\
\hline $\begin{array}{l}\text { Distilled } \\
\text { water }\end{array}$ & 3162 & 3341 & 742 & 708 \\
\hline $\mathrm{HNO}_{3}$ & 3033 & 2635 & 638 & 758 \\
\hline $\mathrm{H}_{2} \mathrm{SO}$ & 5651 & 5591 & 852 & 850 \\
\hline $\mathrm{NaOH}^{\mathrm{NaO}}$ & 5829 & 5051 & 846 & 783 \\
\hline
\end{tabular}

Values for ultimate tensile strength and ultimate elongation are average values from three test samples.

Table 5

Mechanical Propertles from Ansell Edmont Gloves

After 1 wash-dry cycle

\begin{tabular}{|l|l|l|l|l|}
\hline $\begin{array}{l}\text { Test } \\
\text { Group }\end{array}$ & $\begin{array}{l}\text { Uitimate } \\
\text { Tensile } \\
\text { Strength, } \\
\text { psi } \\
1990\end{array}$ & $\begin{array}{l}\text { Uitmate } \\
\text { Tensille } \\
\text { Strength, } \\
\text { pai } \\
1992\end{array}$ & $\begin{array}{l}\text { Uitimate } \\
\text { Elongation, } \\
\text { percent } \\
1990\end{array}$ & $\begin{array}{l}\text { Urimate } \\
\text { Elongation, } \\
\text { perceni } \\
1992\end{array}$ \\
\hline $\begin{array}{l}\text { As } \\
\text { Received }\end{array}$ & 5532 & 5276 & 813 & 788 \\
\hline Heat aged & 4735 & 3427 & 746 & 737 \\
\hline $\begin{array}{l}\text { Distilled } \\
\text { water }\end{array}$ & 3886 & 3215 & 758 & 708 \\
\hline $\mathrm{HNO}_{3}$ & 1835 & 591 & 717 & 433 \\
\hline $\mathrm{H}_{2} \mathrm{SO}_{4}$ & 5495 & 5486 & 829 & 817 \\
\hline $\mathrm{NaOH}$ & 5820 & 4159 & 804 & 754 \\
\hline
\end{tabular}


Table 6

Mechanical Properties from Ansell Edmont Gloves

After 2 wash-dry cycles

\begin{tabular}{|l|l|l|l|l|}
\hline $\begin{array}{l}\text { Test } \\
\text { Group }\end{array}$ & $\begin{array}{l}\text { Uitmate } \\
\text { Tensile } \\
\text { Strength, } \\
\text { pal } \\
1990\end{array}$ & $\begin{array}{l}\text { Uidmate } \\
\text { Tensile } \\
\text { Strength, } \\
\text { pal } \\
1992\end{array}$ & $\begin{array}{l}\text { Urdmate } \\
\text { Elongation, } \\
\text { percent } \\
1990\end{array}$ & $\begin{array}{l}\text { Uitmate } \\
\text { Elongation, } \\
\text { percent } \\
1992\end{array}$ \\
\hline $\begin{array}{l}\text { As } \\
\text { Received }\end{array}$ & 5652 & 5509 & 808 & 813 \\
\hline Heat aged & 4910 & 4437 & 783 & 763 \\
\hline $\begin{array}{l}\text { Sistlled } \\
\text { water }\end{array}$ & 3719 & 3721 & 752 & 754 \\
\hline $\mathrm{HNO}_{3}$ & 4215 & 209 & 850 & 417 \\
\hline $\mathrm{H}_{2} \mathrm{SO}_{4}$ & 5735 & 4949 & 842 & 767 \\
\hline $\mathrm{NaOH}$ & 5473 & 4968 & 850 & 765 \\
\hline
\end{tabular}

Values for ultimate tensile strength and uldmate elongation are average values from three test samples.

Table 7

Mechanical Propertles from Ansell Edmont Gloves

After 3 wash-dry cycles

\begin{tabular}{|c|c|c|c|c|}
\hline $\begin{array}{l}\text { Test } \\
\text { Group }\end{array}$ & $\begin{array}{l}\text { Utimate } \\
\text { Tentlle } \\
\text { Strength, } \\
\text { psi } \\
1990\end{array}$ & $\begin{array}{l}\text { Uidmate } \\
\text { Tenalle } \\
\text { Strength, } \\
\text { pai } \\
1992\end{array}$ & $\begin{array}{l}\text { Urtimate } \\
\text { Elongation, } \\
\text { percent, } \\
1990\end{array}$ & $\begin{array}{l}\text { Uitmate } \\
\text { Elongatlon, } \\
\text { percent, } \\
1992\end{array}$ \\
\hline $\begin{array}{l}\text { As } \\
\text { Received }\end{array}$ & 5682 & 5203 & 796 & 786 \\
\hline Heat aged & 5165 & 4263 & 829 & 746 \\
\hline $\begin{array}{l}\text { Distilled } \\
\text { water }\end{array}$ & 4301 & 4026 & 802 & 777 \\
\hline $\mathrm{HNO}_{3}$ & 2985 & 2565 & $740^{\circ}$ & 633 \\
\hline $\mathrm{H}_{2} \mathrm{SO}_{4}$ & 3453 & 4862 & 796 & 802 \\
\hline $\mathrm{NaOH}$ & 5532 & 4794 & 827 & 783 \\
\hline
\end{tabular}


Table 8

Mechanical Propertles from Ansell Edmont Gloves

After 4 wash-dry cycles

\begin{tabular}{|l|l|l|l|l|}
\hline $\begin{array}{l}\text { Test } \\
\text { Group }\end{array}$ & $\begin{array}{l}\text { Utimate } \\
\text { Tensile } \\
\text { Strength, } \\
\text { pal 1990 }\end{array}$ & $\begin{array}{l}\text { Utimate } \\
\text { Tensile } \\
\text { Strength, } \\
\text { pal 1992 }\end{array}$ & $\begin{array}{l}\text { Uitmate } \\
\text { Elongation, } \\
\text { percent, } \\
1990\end{array}$ & $\begin{array}{l}\text { U1tmate } \\
\text { Elongation, } \\
\text { percent, } \\
1992\end{array}$ \\
\hline $\begin{array}{l}\text { As } \\
\text { Received }\end{array}$ & 5185 & 5129 & 798 & 767 \\
\hline Heat aged & 4432 & 4542 & 792 & 794 \\
\hline $\begin{array}{l}\text { Distlled } \\
\text { water }\end{array}$ & 4243 & 4119 & 804 & 767 \\
\hline $\mathrm{HNO}_{3}$ & 5129 & 3089 & 831 & 633 \\
\hline $\mathrm{H}_{2} \mathrm{SO}_{4}$ & 5233 & 4777 & 792 & 781 \\
\hline $\mathrm{NaOH}$ & 5293 & 5100 & 775 & 765 \\
\hline
\end{tabular}

Values for ultimate tensile strength and ultimate elongation are average values from three test samples.

Table 9

Mechanical Propertes from Ansell Edmont Gloves

After 5 wash-dry cycles

\begin{tabular}{|l|l|l|l|l|}
\hline $\begin{array}{l}\text { Test } \\
\text { Group }\end{array}$ & $\begin{array}{l}\text { Uidmate } \\
\text { Tenalle } \\
\text { Strength, } \\
\text { pol } \\
1990\end{array}$ & $\begin{array}{l}\text { Uidmate } \\
\text { Tenalle } \\
\text { Strength, } \\
\text { pol } \\
1992\end{array}$ & $\begin{array}{l}\text { Uitrate } \\
\text { Elongation, } \\
\text { percent } \\
1990\end{array}$ & $\begin{array}{l}\text { Uitmate } \\
\text { Elongation, } \\
\text { percent } \\
1992\end{array}$ \\
\hline $\begin{array}{l}\text { As } \\
\text { Received }\end{array}$ & 5363 & 4733 & 775 & 742 \\
\hline Heat aged & 4921 & 4332 & 792 & 708 \\
\hline $\begin{array}{l}\text { Distilled } \\
\text { water }\end{array}$ & 3878 & 3889 & 767 & 696 \\
\hline $\mathrm{HNO}_{3}$ & 3759 & 965 & 783 & 483 \\
\hline $\mathrm{H}_{2} \mathrm{SO}_{4}$ & 5441 & 5468 & 779 & 775 \\
\hline $\mathrm{NaOH}^{\mathrm{NOOH}}$ & 5229 & 5512 & 771 & 792 \\
\hline
\end{tabular}


Table 10

Mechanical Propertles from Ansell Edmont Gloves

After 6 wash-dry cycles

\begin{tabular}{|l|l|l|l|l|}
\hline $\begin{array}{l}\text { Test } \\
\text { Group }\end{array}$ & $\begin{array}{l}\text { Urimate } \\
\text { Tensile } \\
\text { Strength, } \\
\text { psi } \\
1990\end{array}$ & $\begin{array}{l}\text { Urimate } \\
\text { Tensile } \\
\text { Strength, } \\
\text { psi } \\
1992\end{array}$ & $\begin{array}{l}\text { Utimate } \\
\text { Elongatlon, } \\
\text { percent } \\
1990\end{array}$ & $\begin{array}{l}\text { Utimate } \\
\text { Elongation, } \\
\text { percent } \\
1992\end{array}$ \\
\hline $\begin{array}{l}\text { As } \\
\text { Received }\end{array}$ & 5228 & 5282 & 783 & 767 \\
\hline Heat aged & 4286 & 3810 & 742 & 746 \\
\hline $\begin{array}{l}\text { Distilled } \\
\text { water }\end{array}$ & 3979 & 3623 & 752 & 704 \\
\hline $\mathrm{HNO}_{3}$ & 4967 & 1052 & 858 & 483 \\
\hline $\mathrm{H}_{2} \mathrm{SO}_{4}$ & 5569 & 5143 & 825 & 800 \\
\hline $\mathrm{NaOH}^{2}$ & 5435 & 4729 & 817 & 746 \\
\hline
\end{tabular}

Values for uldmate tenalle atrength and ultmate elongation are average values from three test samples.

Table 11

Mechanical Properties from Ansell Edraont Gloves

After 7 wash-dry cycles

\begin{tabular}{|c|c|c|c|c|}
\hline $\begin{array}{l}\text { Teat } \\
\text { Group }\end{array}$ & $\begin{array}{l}\text { Uidmate } \\
\text { Tensille } \\
\text { Strength, } \\
\text { pal } \\
1990\end{array}$ & $\begin{array}{l}\text { Uridmate } \\
\text { Tensile } \\
\text { Strength, } \\
\text { pal } \\
1992\end{array}$ & $\begin{array}{l}\text { Uitimate } \\
\text { Elonflation, } \\
\text { percent } \\
1990\end{array}$ & $\begin{array}{l}\text { Uitimate } \\
\text { Elongation, } \\
\text { percent } \\
1992\end{array}$ \\
\hline $\begin{array}{l}\text { As } \\
\text { Received }\end{array}$ & 5477 & 4906 & 808 & 758 \\
\hline Heat aged & 4450 & 3839 & $7 \pi 7$ & 733 \\
\hline $\begin{array}{l}\text { Distilled } \\
\text { water }\end{array}$ & 3649 & 3834 & 758 & 750 \\
\hline $\mathrm{HNO}_{3}$ & 3862 & 2487 & 8150 & 725 \\
\hline $\mathrm{H}_{2} \mathrm{SO}_{4}$ & 4548 & 4938 & 767 & 775 \\
\hline$\overline{\mathrm{NaOH}}$ & 5446 & 4965 & 808 & 788 \\
\hline
\end{tabular}


Table 12

Permeabillty Data for Ansell Edmont Gloves

\begin{tabular}{|l|l|l|}
\hline $\begin{array}{l}\text { Specimen } \\
\text { number }\end{array}$ & $\begin{array}{l}\text { Finish } \\
\mathrm{cm}^{3} \mathrm{~cm} \\
\mathrm{~cm}^{2} \mathrm{Bg}\end{array}$ \\
\hline 1 & $\frac{2052,16 \times 10^{-13}}{}$ \\
\hline 2 & rough & $3234.60 \times 10^{-13}$ \\
\hline 3 & rough & $2760.26 \times 10^{-13}$ \\
\hline 4 & rough & dummy \\
\hline 5 & rough & $1570.93 \times 10^{-13}$ \\
\hline 6 & 2unooth & $1664.03 \times 10^{-13}$ \\
\hline 7 & emooth & $4510.50 \times 10^{-13}$ \\
\hline 8 & smooth & dummy \\
\hline
\end{tabular}

Table 13

Permeability Data for North Brothers Gloves

\begin{tabular}{|l|l|l|}
\hline $\begin{array}{l}\text { Specimen } \\
\text { number }\end{array}$ & Finish & $\begin{array}{l}\text { Permeabllity } \\
\mathrm{cm}^{3} \mathrm{~cm} \\
\mathrm{~cm}^{2} \cdot \mathrm{Pa}\end{array}$ \\
\hline 9 & $9411.1 \times 10^{-13}$ \\
\hline 10 & rough & $3349.0 \times 10^{-13}$ \\
\hline 11 & roush & $8163.2 \times 10^{-13}$ \\
\hline 12 & roush & dummy \\
\hline 13 & 8mooth & $676.12 \times 10^{-13}$ \\
\hline 14 & 8mooth & $4737.9 \times 10^{-13}$ \\
\hline 15 & smooth & $7694.8 \times 10^{-13}$ \\
\hline 16 & imooth & dummy \\
\hline
\end{tabular}


North Brothers

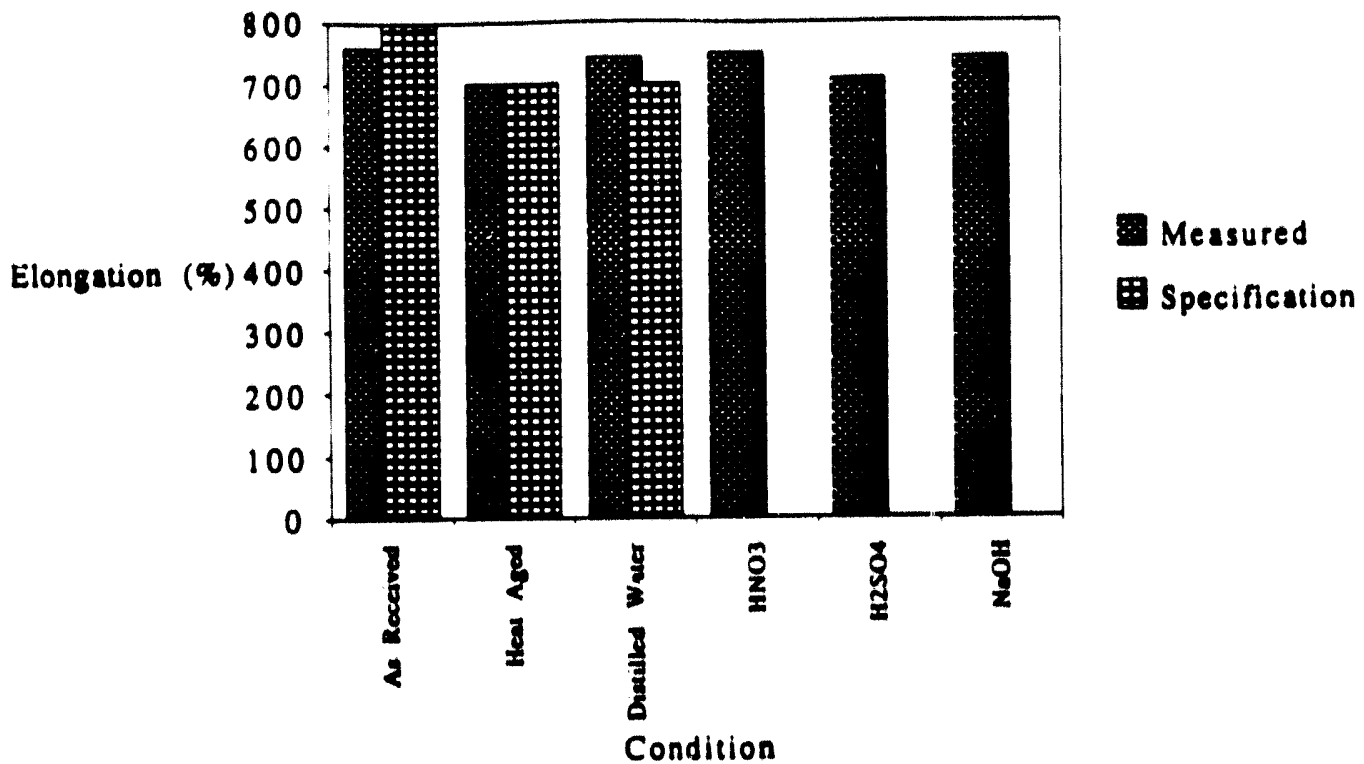

North Brothers

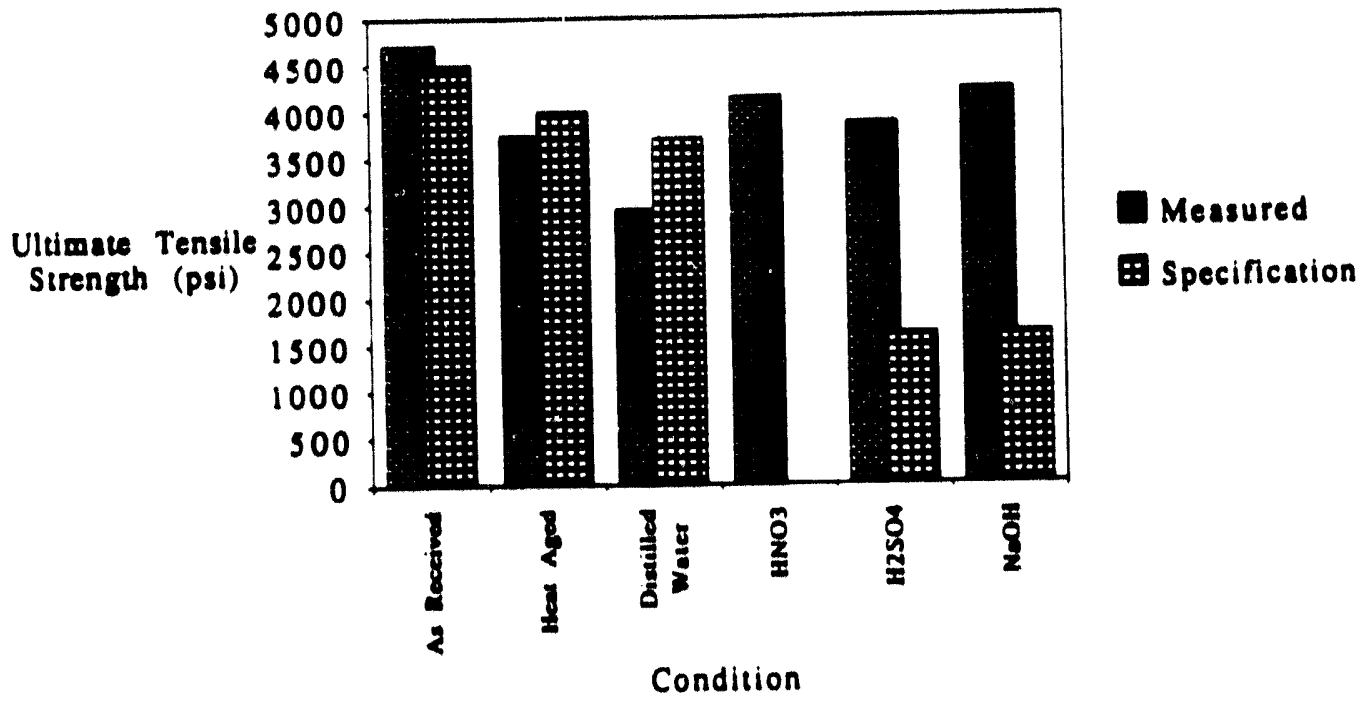

Figure 1. Ulimate tensile strength and elongation percent for North Brothers Gloves. 
1990 Ansell Edmont

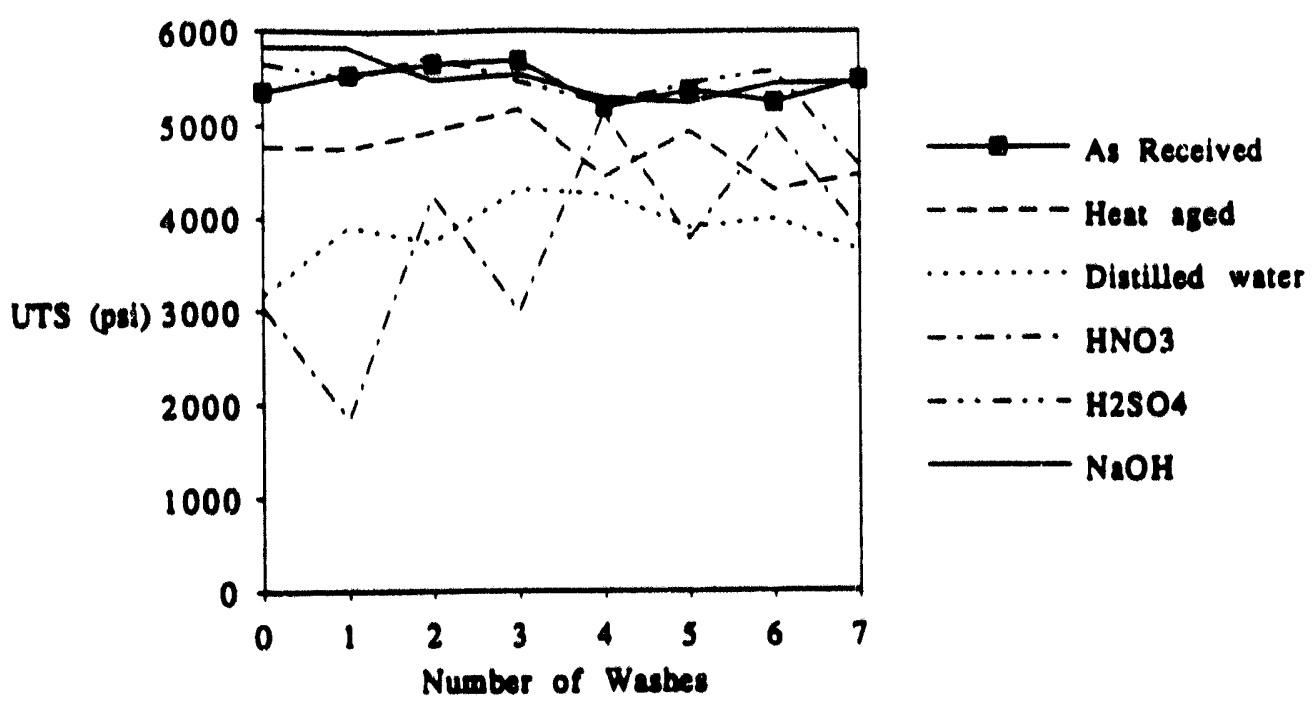

1990 Aneall Edmont

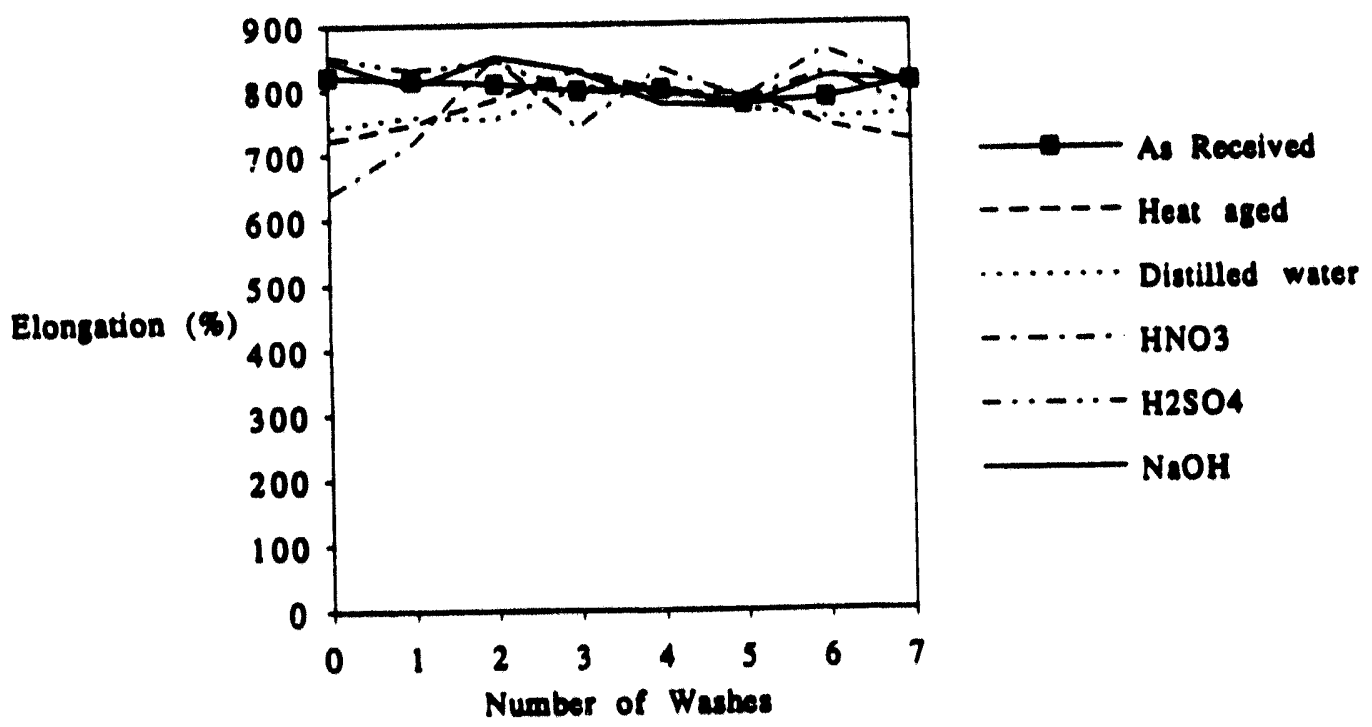

Figure 2. Uitmate tensile strength and elongation percent for. Ansell Edmont Gloves manufactured in 1990. 
1992 Ansell Edmont

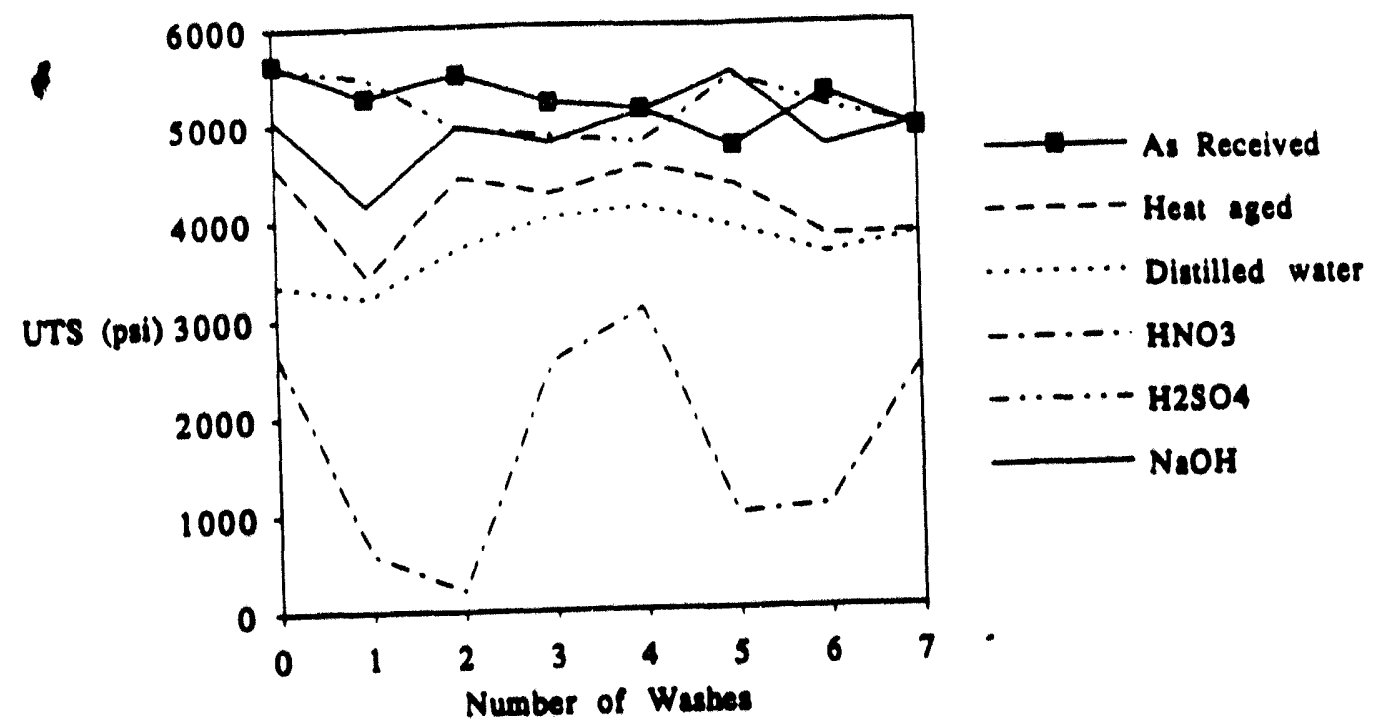

1992 Ansell Edmont

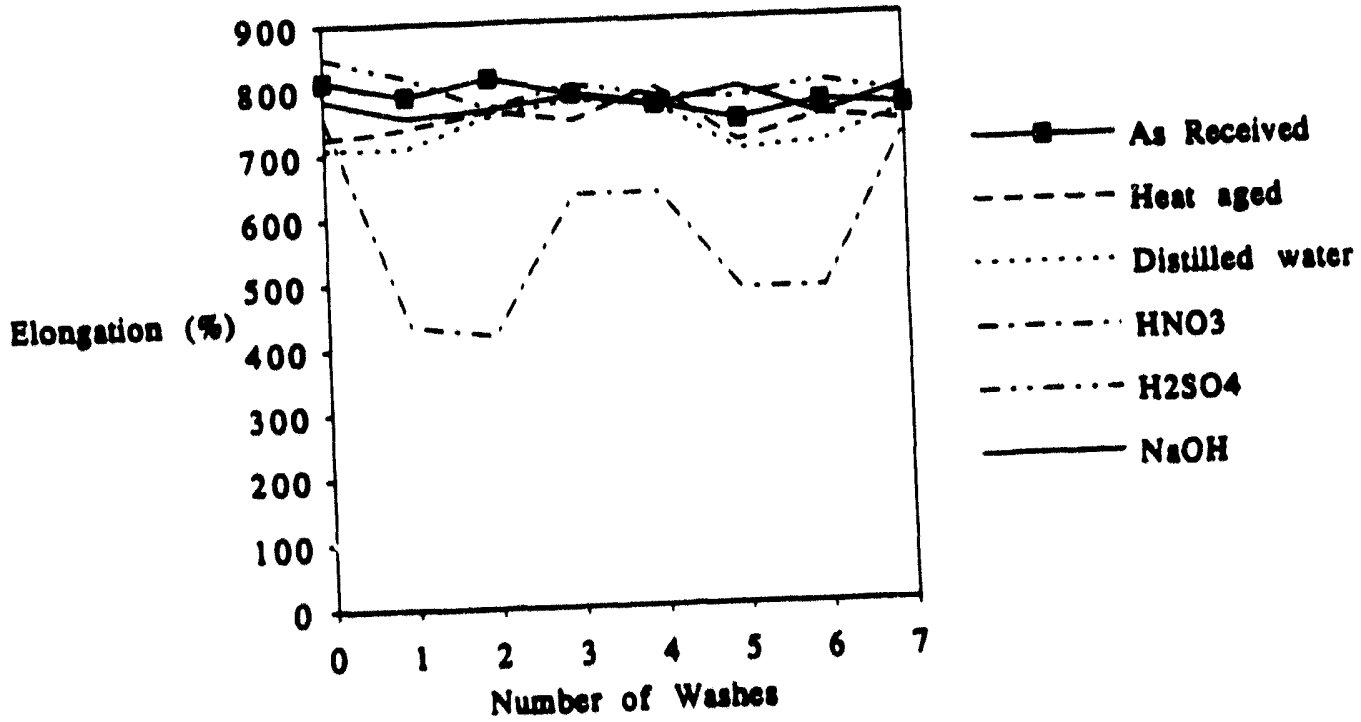

Figure 3. Ulimate tenalle otrength and elongation percent for Ansell Edmoat gloves manufactured in 1992. 

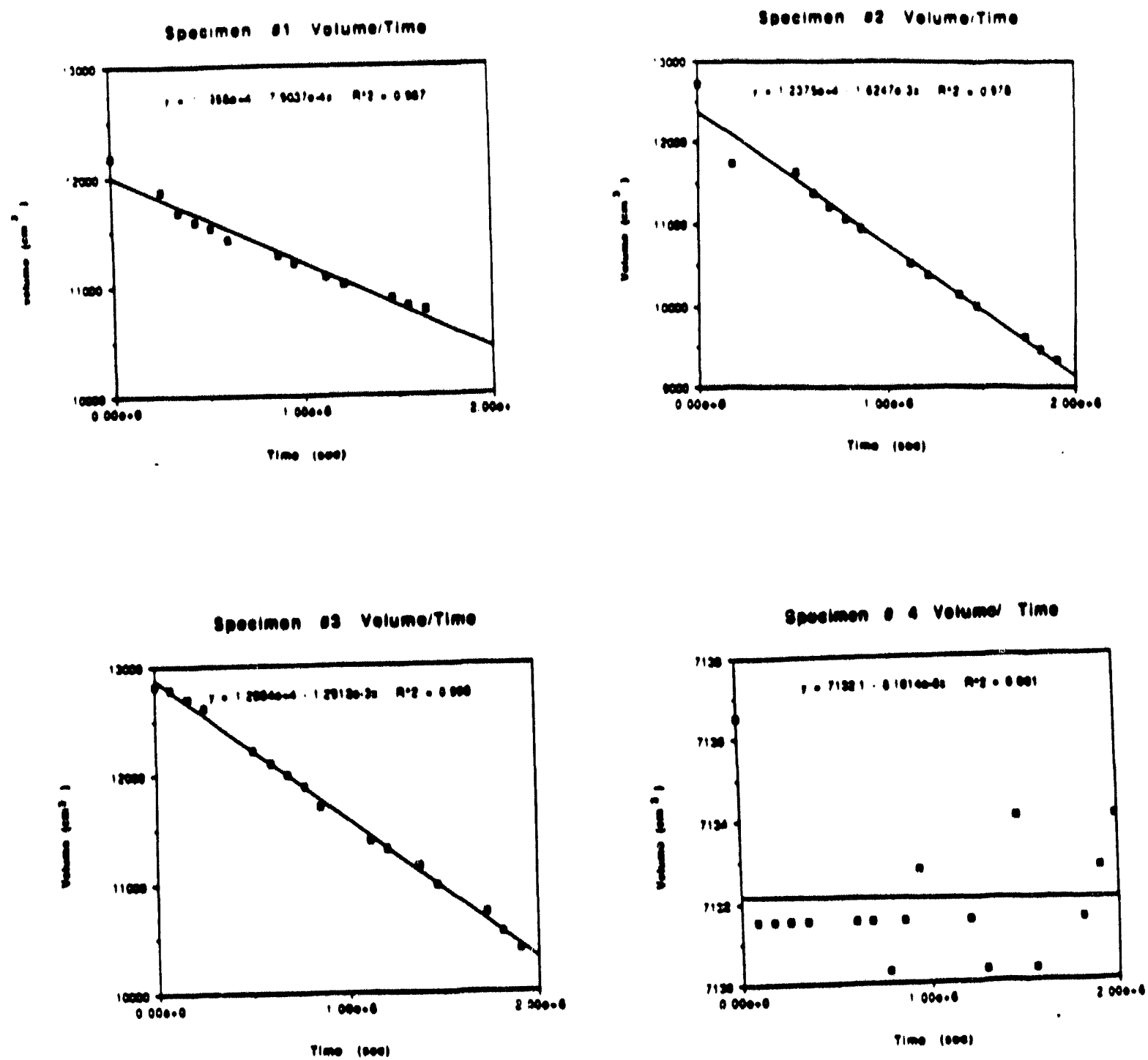

Figure 4. Ansell Bdmont Glove Semplea: Change in quantity of water verous the change in time. Specimens 13 are real amples and Specimen 4 is a "dummy" sample. 

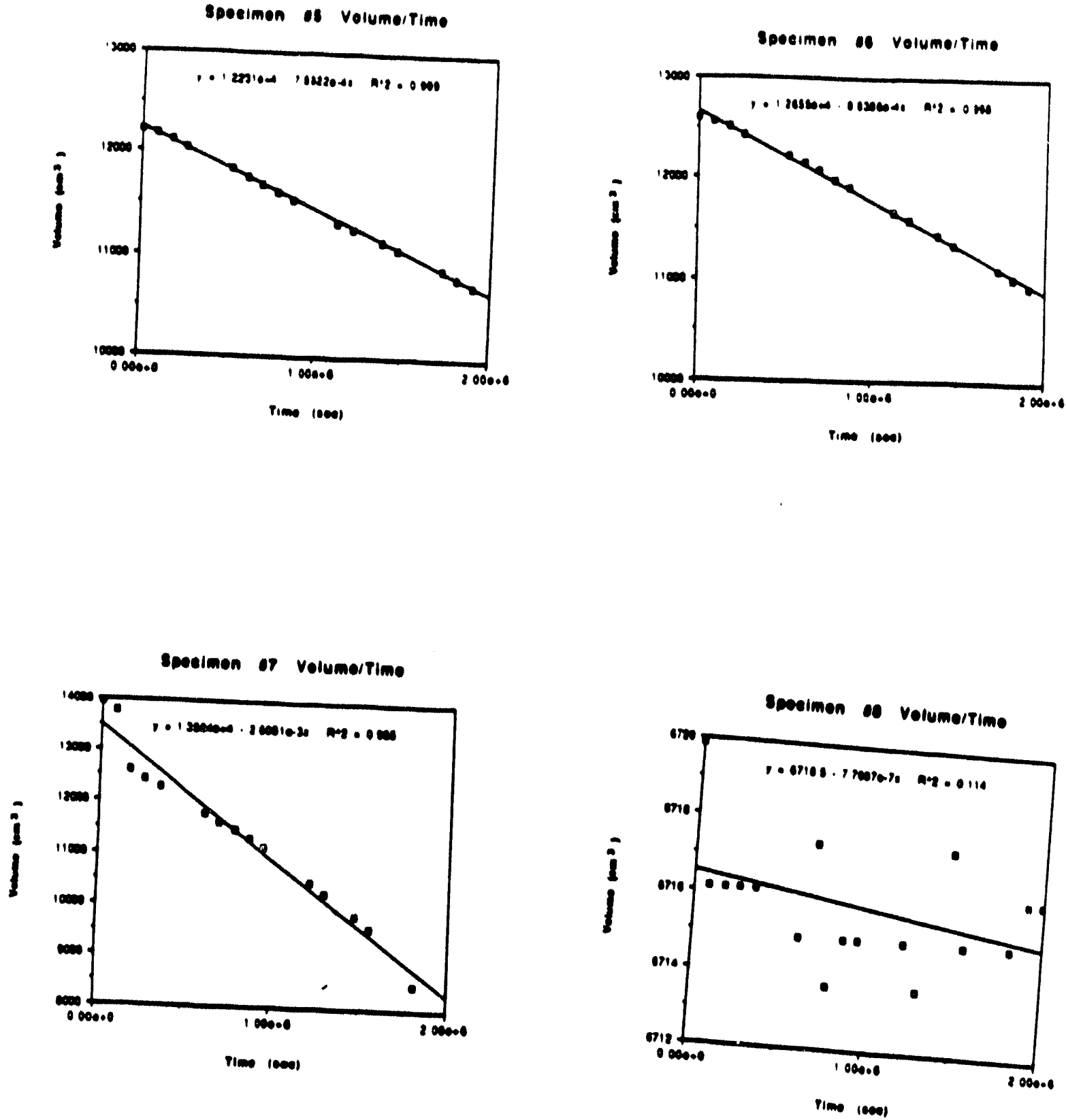

Figure 5. Ansell Edmont Glove Samples: Change in quantity of water verous the change in time. Specimens in 5-7 are real and 8 is the "dummy" sample. 

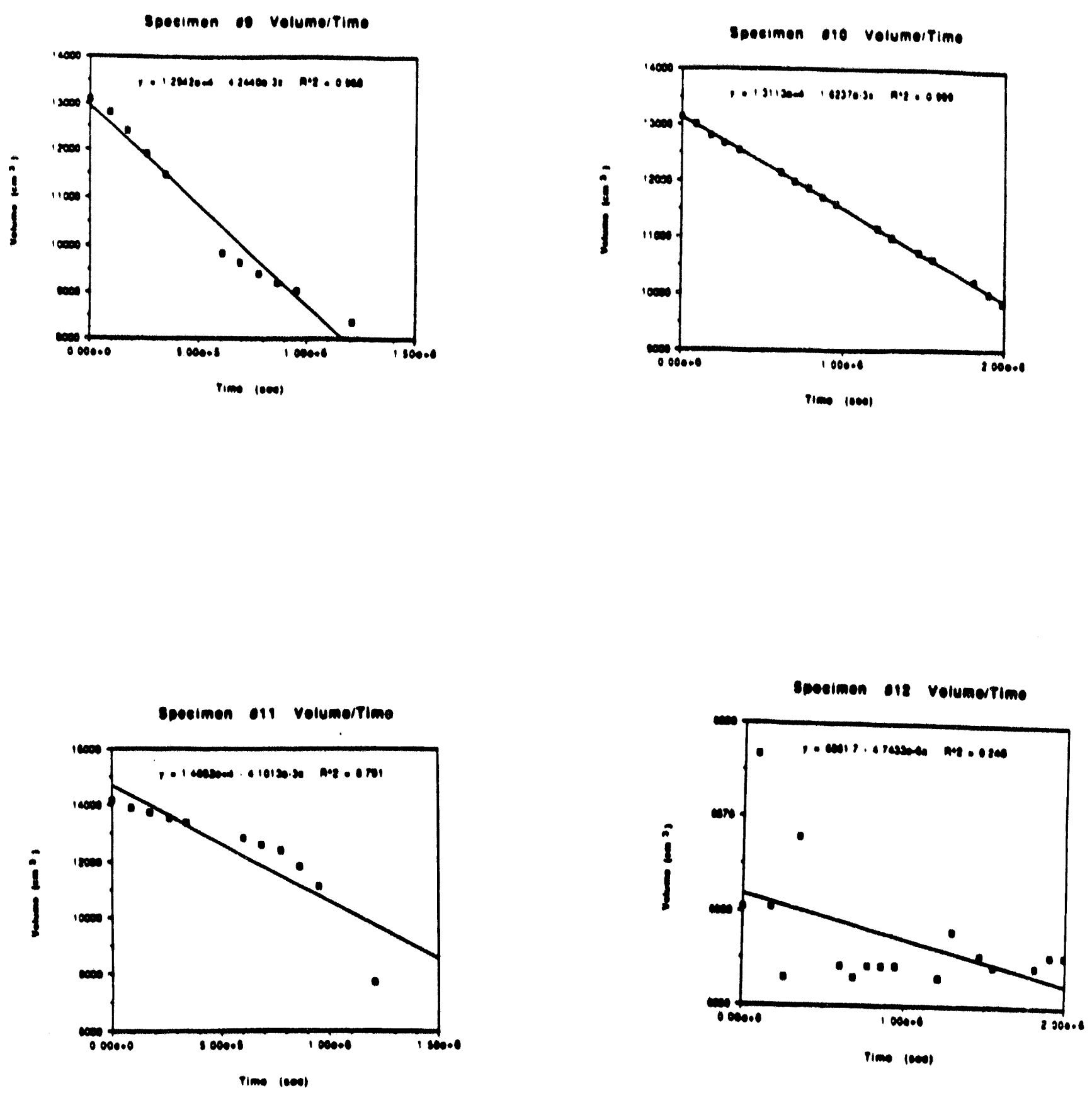

Figure 6. North Brothere glove eamplea: change in quantity verous the change in time. Specimens 9 - 11 are real samples and specimen 12 is the "dummy" 

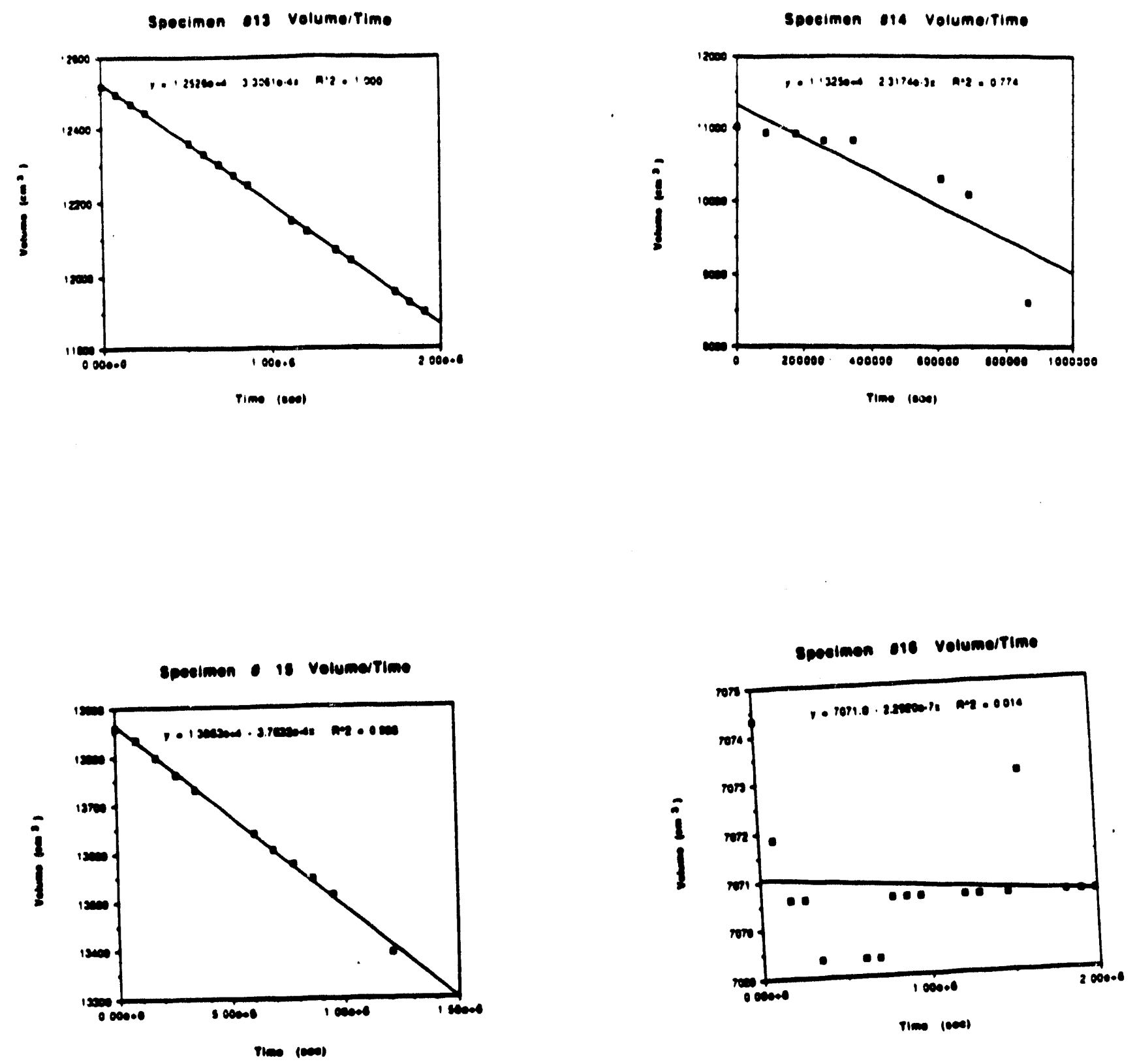

Figure 7. North Brothers glove amples: change in quantity verous the change in time. Sperimens $13-15$ are real eamples and specimen 16 is the "dummy" eample 


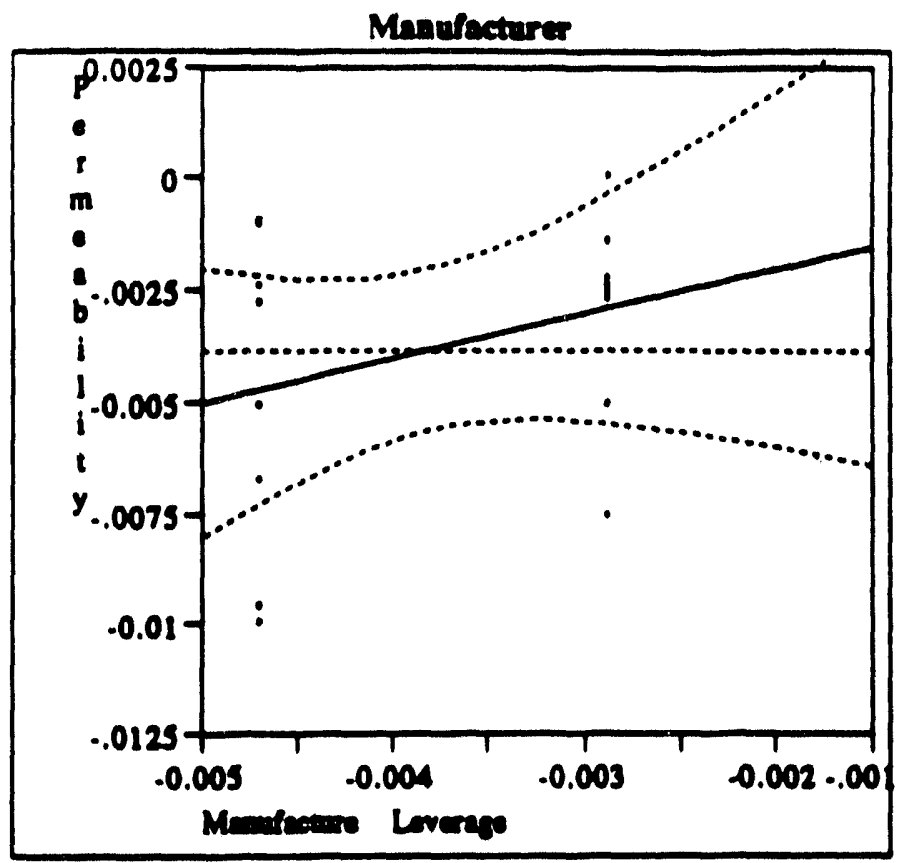

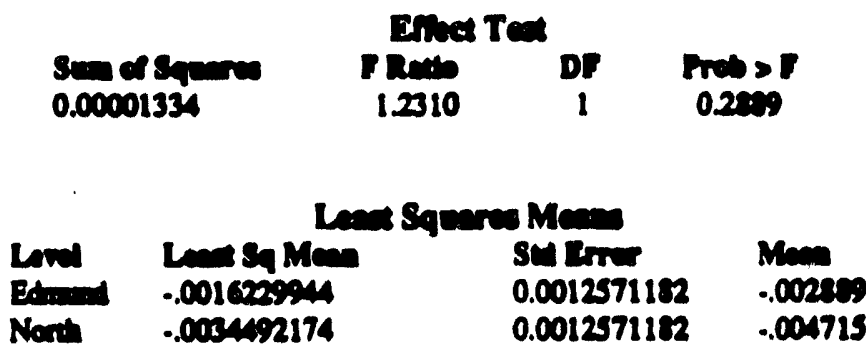

Figure 8 Linear fit of permeability to manufacturer. Lack of interection of the $95 \%$ confidence curve with the hortzontal line indicates no correlation exdets between permeability and the manufacturer. Neo, F otatistic indicates that $29 \%$ of the dime the results would occur by random chance. 
Finish
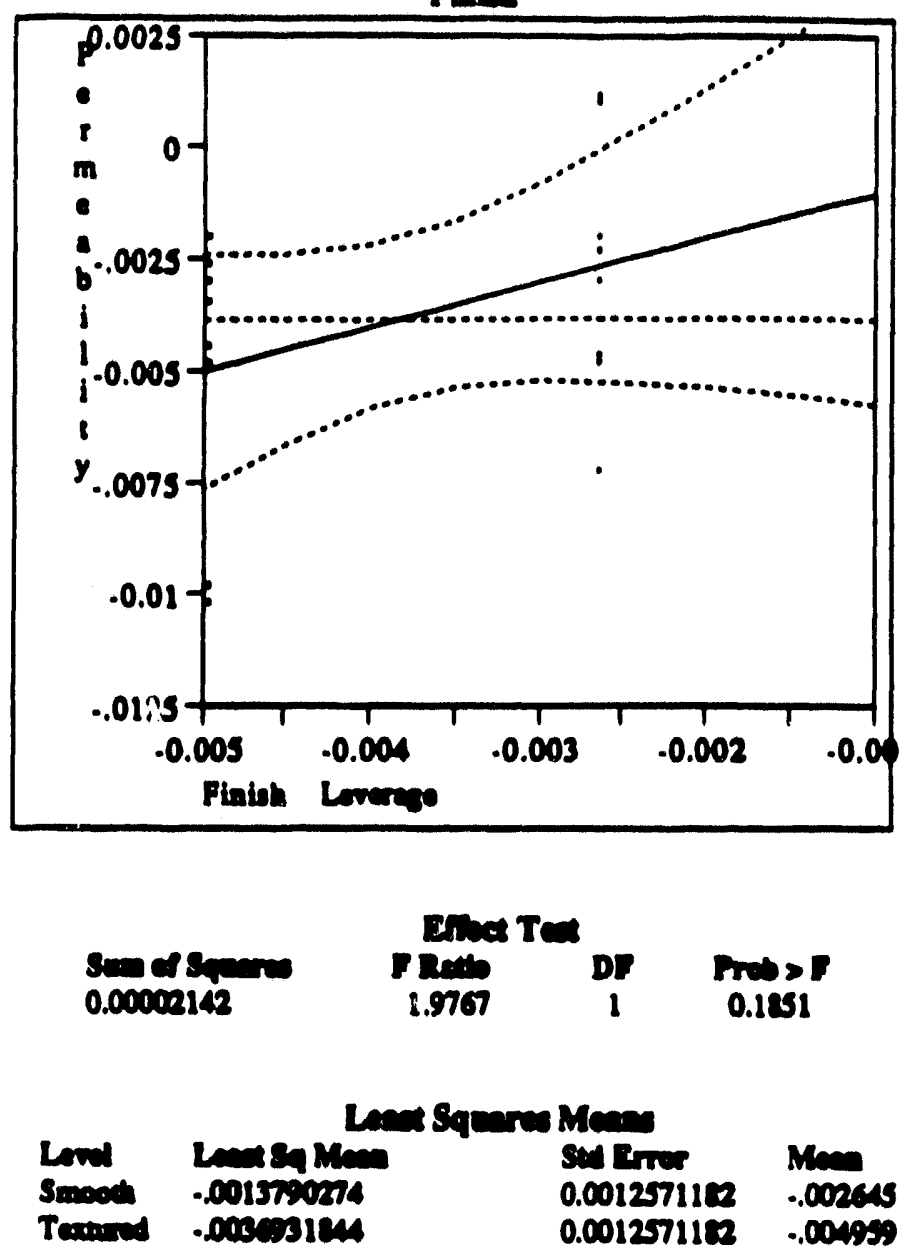

Figure 9. Linear fit of permeabillty to glove finioh. Lack of internectlon of the $95 \%$ confidence curve with the hortzontal line indicates no correlation exdets between permeablitty and the finilah of the glove material. Also, F statiatle indicates that $19 \%$ of the time the results would occur by random chance. 
Trpe

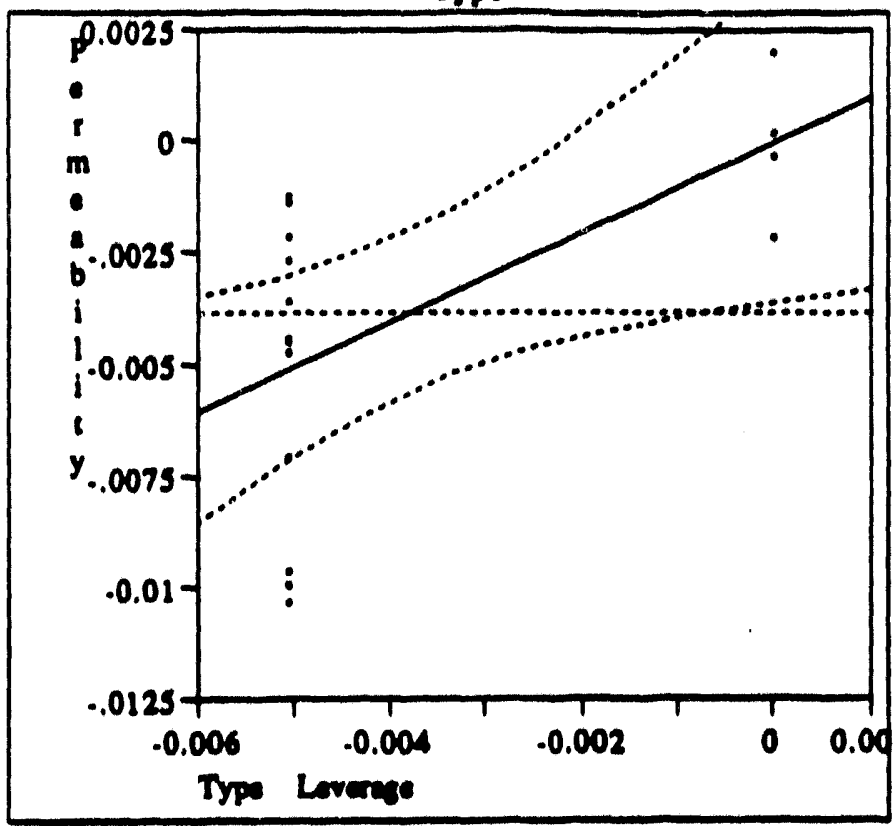

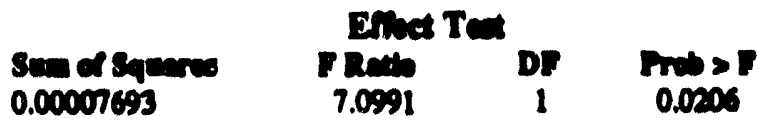

\begin{tabular}{|c|c|c|}
\hline 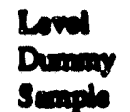 & 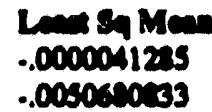 & 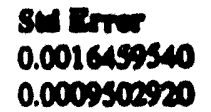 \\
\hline
\end{tabular}

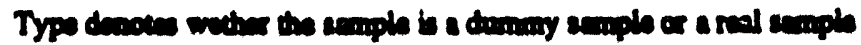

Figure 10. Unear fit of permeablilty to cample type. The Internection of the 95\% confidence curve with the horizontal line indicates that a correlation exdats between permeabllity and whether the anmple io real or a "dummy". Aleo, F stadiatic indicates that $2 \%$ of the time the results would occur by random chance. 

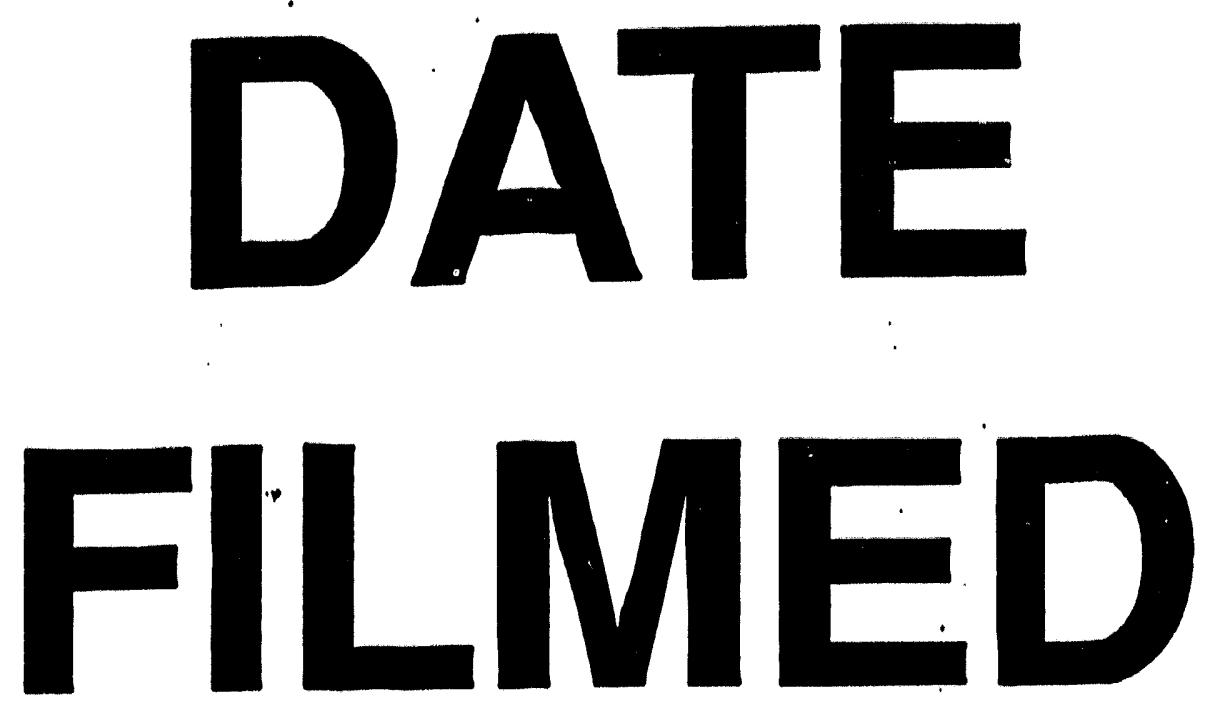

II

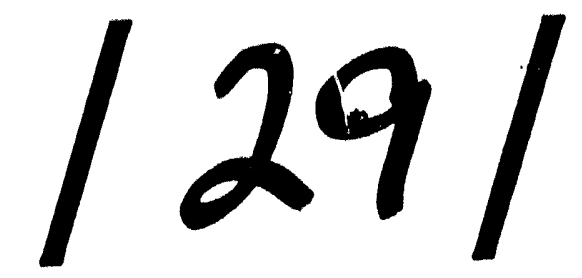

93
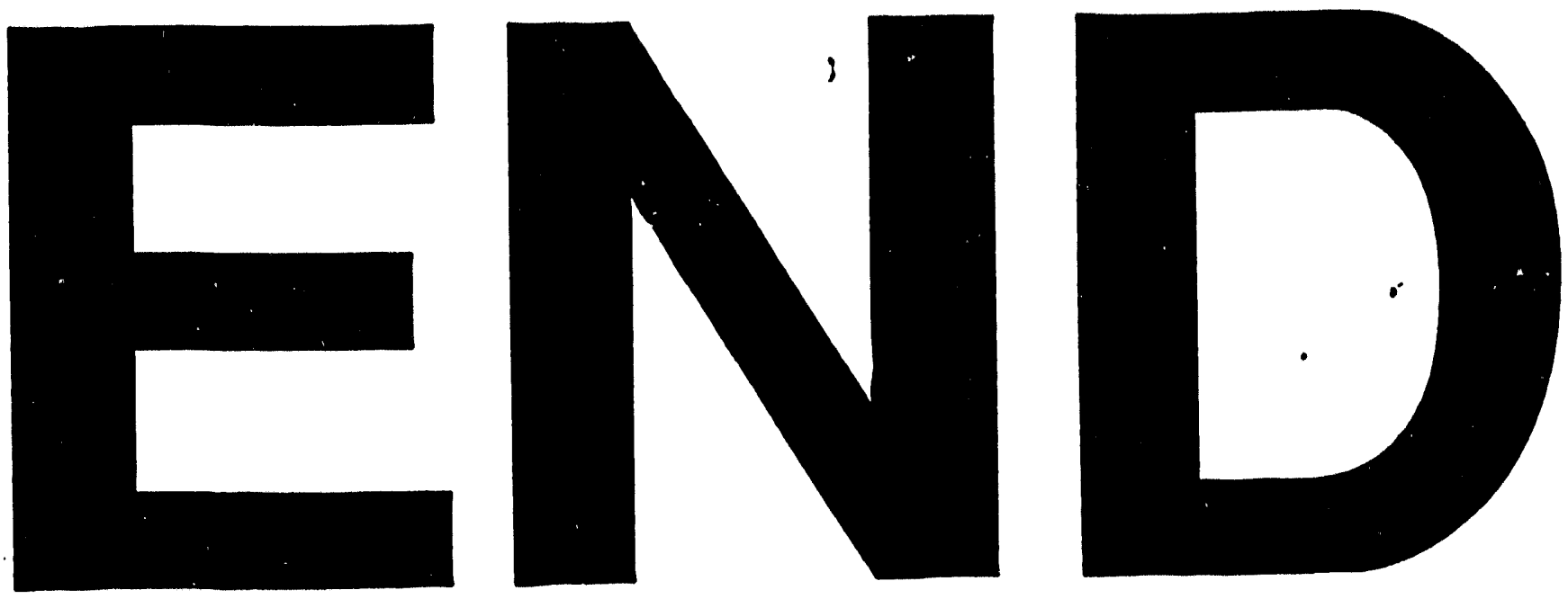


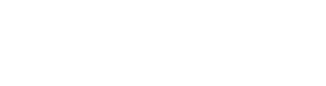

....... 